\title{
Jingpho Language
}

National Cancer Institute

\section{Source}

National Cancer Institute. lingpho Language. NCI Thesaurus. Code C153967.

A T ibeto-Burman language of the Sal branch mainly spoken in the Kachin State of Myanmar and the Yunnan Province of China. 